\title{
FOREWORD
}

\section{WHAT THE BLACK LIVES MATTER MOVEMENT DEMANDS OF ETHNIC STUDIES SCHOLARS}

\author{
Melina Abdullah \\ California State University, Los Angeles \\ Black Lives Matter
}

"Come in. Sit down. Close your eyes. Be silent and listen." Melody engulfed the room. Our bodies unwittingly swayed softly to rhythms that conjured Ancestral memories. The bald, brown-skinned, goateed, dashiki-wearing man in front of the room exuded both warmth and strength. As a fourteen year-old ninth grader, the constancy of my giggle was interrupted by the sanctity of the space. Squeaks of the crotchety wooden desks that formed a large circle joined the music that hummed from the old record player at the front of the room. Minutes felt like days. Sound transported us through time and space and as the song came to an end, Mr. Navies instructed us, in a voice that prolonged the Spirit of what we had just experienced, "Now, write down your thoughts." Silently, we scribbled down the ideas, poems, and stories that danced out of our Souls. We were greeted this way every single morning in African American History, Black Gold English, Black Male-Female Relationships, and the dozens of classes that comprised the Black Studies Department curriculum at Berkeley High School. At the close of each week, we would share our writings with the class, inspired by "classical Black musicians" from Charlie Parker, to Thelonius Monk, to Billie Holliday. Dassine, LaRae, Trinice, and Tomorrow would share poems. Ameer, always sat directly to my left and would break up the passionate tear-eliciting prose shared by others, with stories and jokes so hilarious that $\mathrm{Mr}$. Navies would sometimes have to turn his back and hurriedly race across the room to shield his laughter from the class.

As a Black girl coming of age at the height of the crack cocaine epidemic in East Oakland, Black Studies classes became my refuge and the refuge of an entire generation of Berkeley High School students who flourished during "Back to Black Week" and "Malcolm X Week" when classes were suspended and African-Haitian dance performances, speeches by scholars like Oba T'shaka and Angela Davis, and our own brilliant poetry and essays became massive campus-wide presentations in the school auditorium. Somehow, the murder of my eighth grade boy- 
friend, Curtis Belton, was not quite so haunting. I was able to escape the constant counting of bodies. . .of friends. . .children. . .who were gunned down or imprisoned by systems that sought to dehumanize us on a daily basis. As I wrapped myself in a lapa and danced to drum beats, my heightened sexualization by grown men who sought to prey on me at bus stops was beaten back. Our collective power was harnessed off campus too. When the corner store implemented a racist policy, requiring Black students to enter one at a time (allegedly to prevent shoplifting), we made signs on the floor of Mr. Navies' classroom and picketed for weeks. . .until Blue \& Gold Corner Grocery halted these unjust practices. There were bus trips to Sacramento to challenge policies and conversations that reminded us of the richness and power of our people. Mr. Navies became our savior, who we never dared to tell how much we loved, honored and respected. Black Studies literally saved my life. . our lives.

Leukemia took the body of Richard Navies before I ever got the chance to tell him any of this, before I earned my degree in African American Studies from Howard University, before I went on to graduate school, before I became a professor of Pan-African Studies, before I became a mama, or a full-fledged community organizer. I watched him watch me come to class high, sit out in front of the school and flirt with the boys who rolled up in Mercedes and five-point-0s, begin to mold myself into the person that my environment imposed. I became a "fly girl," a drug-dealer's girlfriend. I dropped out of traditional school and relied on my physical appearance rather than my intellect. I do not know if he knows how the seeds that he planted took root, that those moments of imposed identities were impermanent and how the foundation that he laid for us formed the core of our beings. I pray that his Spirit sees how deeply committed we all are to honoring him with our work.

I share this experience in hopes of reminding Ethnic Studies scholars of our power and purpose. So many of us were pulled into the discipline not because of aspirational career trajectories, but because our very Souls commanded it. Our work is deeply personal and driven by what it produces for the collective. And while so many of us are in institutions, we must not become of it. Ethnic Studies is meant to liberate. . to be an antidote to crack cocaine epidemics, to media images that degrade Black bodies, to intersectional everyday oppressions, to systems of mis-education. Ethnic Studies is meant to echo and deepen calls for liberation and empowerment. . and most loudly and most clearly in this moment to affirm that Black Lives Matter.

As scholars, we are driven to research and publish. We engage critical questions and attempt to contribute to the body of knowledge. We are trained to measure our success by the degree to which our work is discussed and cited by other scholars. Entire reports are generated that ana- 
lyze the reach of our work in this way. Considerations are further bolstered by subjective determinations around the relative importance of research questions and the ranking of the journals or university presses that publish our work. Rarely do we examine the impact, or lack thereof, that our work has on the world of which we are a part.

Under such a model, academics can choose to reject, ignore, or challenge from the comfort of "reserved" padded corner chairs at Starbuck's or university clubs, the experiences, realities, and struggles of people who become objects for analysis, variables in equations. Even in historic moments like the one in which we currently find ourselves, where Black people and allies are refusing to get in line, boldly challenging power, and demanding not just reform, but transformation, many academics remain so tied to research agendas that they continue to churn out regression analyses that highlight their own mathematical genius or theoretical pieces that obsess in the coining of terms which carry no meaning for the vast majority of people. And then there are the others, those who monitor trends and whose writing jumps and shifts to accommodate, to keep the scholar "hot." While, their work is often more accessible and relevant to the public, these scholars write (and sometimes study) upon communities rather than with them. Their work is for the purposes of advancing their own careers and profiles. This Black Lives Matter moment challenges scholars to do something different. As spaces are disrupted and attempts are made to completely reimagine key systems. . from public safety to education. . .we must also reconsider our own roles.

As Ethnic Studies scholars, we must refuse to align with principles and practices that have never benefitted people of color and oppressed communities. We are challenged to recall and adhere to the revolutionary foundations of our discipline that transform the lives of entire generations, empower communities, and inspire and support radical action. Ethnic Studies was never meant to be a part of the ivory tower, but to disrupt it. Ethnic Studies scholars who are true to our field are not academics, but intellectuals whose work must challenge the order of things and should make a contribution to freedom and justice struggles. "There is no politically neutral intellectual work. Knowing this should empower intellectuals to make political choices that we can claim while still holding on to an ethical commitment of open engagement with ideas. Intellectuals can offer any radical movement for social change transformative visions and insights" (bell hooks, Killing Rage: Ending Racism, 239).

This rejection of the false notion of neutrality challenges us to constantly remember whose side we are on. . .we must always, unwaveringly, be on the side of the people, not simply conceptually, but tangibly. Bell hooks' call is meant to challenge scholars broadly to become intel- 
lectuals rather than academics and is rooted in the praxis of Ethnic Studies. Our field was not birthed by research questions, but by a resistance movement entrenched in community calls for liberation. The 1968 community and student struggle that gave rise to our field was one component of the broader Black and Third World liberation struggle; it was not simply simultaneous to the Black Power Movement, but a part of it. In many senses, our field is one of the movement's greatest and most enduring victories. As such, our work is meant to deepen the intellectual frame from which we struggle, with active engagement constantly informing and benefiting from our work. For Ethnic Studies scholars, intellectual work must necessarily be movement work.

We must also understand the movement as continuous and enduring. As Angela Davis reminds us, "freedom is a constant struggle." We are at a deeply critical juncture. Black Lives Matter, born in 2013, is a moment of reawakening, reimagining, and rebuilding of the Black freedom movement. Inasmuch as Black Lives Matter is a collective outcry that honors the life of Trayvon Martin, Mike Brown, Ezell Ford, Aiyana Stanley-Jones, Tamir Rice, Redel Jones, Wakiesha Wilson, Emmitt Till, Malcolm X, Nat Turner, and the thousands of others whose lives were stolen by the state, this iteration of the movement is more than a response. Black Lives Matter was built to topple state-sanctioned violence against Black people and has worked for more than three years to disrupt the policing system that was built intentionally and deliberately to target Black people for demise. It was birthed to dismantle policing as a tool of White-supremacist-patriarchal-heteronormative-capitalism. And more than that, it challenges us to wake up, step up, struggle for, vision, and build Black freedom, recalling Mama Harriet Tubman's admonition to "be free or die."

Just as Black Lives Matter embraces the disrupt/build model. . .one that directly challenges institutions, while visioning and building liberatory models. Ethnic Studies scholars are challenged to determine how to fully engage as intellectuals. In what ways can our research, writing, classrooms, and campuses serve as spaces for disruption and building? How will the political decisions that we make as scholars confirm that we are on the side of the people? How well will we adhere to the calls of our discipline to fully entrench ourselves in the Black freedom movement that is currently taking form as Black Lives Matter? I submit that all of us must commit three things to the movement: voice, body, and resources. Voice means amplifying the call for Black freedom as expressed through Black Lives Matter. As intellectuals, we are uniquely positioned to do this piece of the work. We have an opportunity to counter the heavily resourced rhetoric of institutions by lifting up the voices of the people through our research and writing. This is one of the 
functions and intentions of this journal edition. And we must go further. The second commitment that we must make. . that of our body. . .means that we must show up. It is not enough to write about what we read or watch in media. Intellectual work entrenched in the movement means that we must participate with the folks on the front lines. The energy and power of the movement cannot be understood or fully captured through interviews and focus groups. This moment requires action research in partnership with fully engaged practitioners. Finally, we must commit resources. Campuses are spaces of tremendous resource, even the underfunded ones. There is classroom space that can double as meeting space. There are funds for speakers and activities. There are copy machines. There are people - students, faculty and staff, whose lives do not begin and end with their roles on campus.

It is not coincidental that nearly half of those who heeded the call of Patrisse Cullors (who had been in conversation with Alicia Garza and Opal Tometi) to convene the night of July 13, 2013 were Pan-African Studies students. There were a million stars that night as we gathered in the courtyard of St. Elmo's Village. . the Black artist community where Patrisse was living. As we held hands, committed to build the Black Lives Matter movement as more than a response moment, and chanted "Assata," we were also honoring the traditions carried by Mr. Navies, C.R.D. Halisi, Manning Marable, Huey P. Newton, Cedric Robinson, and all of the other Black Studies and Ethnic Studies scholars who have walked before us, who have forged a path of revolutionary intellectual work that, at its core, is meant to get us free. May the Black Lives Matter edition of the Ethnic Studies Review jar us into recognizing that our work must refuse the confines of academia; it must be in the tradition of revolutionary intellectualism; it must be entrenched in movement. 